\title{
The Triangle that could Square the Circle? The UN International Convention on the Protection of the Rights of All Migrant Workers and Members of Their Families, the EU and the Universal Periodic
}

\section{Review}

\author{
Alan Desmond \\ Faculty of Law, University College Cork, Western Road, Cork, Ireland \\ E-mail:alandesmond@gmail.com
}

\begin{abstract}
Even before it had been fully drafted, the Un International Convention on the Protection of the Rights of All Migrant Workers and Members of Their Families was blighted by a debilitating lack of support from States. Described by one of the participants in the drafting process as the UN's best-kept secret, it remains the least popular of the ten core international human rights instruments and has not been signed or ratified by any of the $28 \mathrm{EU}$ Member States. This article is the first substantive examination of the Convention in the context of the UN's universal periodic review. It suggests that the universal periodic review may give the kiss of EU life to the Convention by raising awareness of it, re-energising civil society to more actively advocate for its ratification and forcing Member States to once again justify non-ratification.
\end{abstract}

\section{Keywords}

UN International Convention on the Protection of the Rights of All Migrant Workers and Members of Their Families - treaty ratification - EU migration law and policy universal periodic review 
The U N International Convention on the Protection of the Rights of All Migrant Workers and Members of their Families (ICMW) was adopted by consensus by the UN General Assembly on 18 December 1990. It is one of the ten core international human rights instruments ${ }^{1}$ and in terms of ratification is demonstrably the least successful of these ten documents. It was not until 2003, 13 years after being opened for signature by all States, that the ICMW gained the requisite 20 ratifications which allowed its entry into force. In the intervening 11 years a further 27 States have ratified the Convention, bringing the total number of States Parties to $47 .^{2}$

A brief comparison of the ratification rate of other core instruments is instructive. The International Convention for the Protection of All Persons from Enforced Disappearance, following ratification by 20 States, entered into force in December 2010, less than four years after it was opened for signature by all States. There are currently 42 States Parties to the Convention. The Convention on the Rights of Persons with Disabilities (CRPD) entered into force in May 2008, just over a year after it was opened for signature, and currently has 147 States Parties. The Convention on the Rights of the Child (CRC) entered into force in September 1990, less than a year after it was opened for signature. There are currently 194 States Parties to the CRC.

It is clear then that despite the consensus surrounding its adoption by the General Assembly in 1990, the ICMW is singularly unpopular amongst many States, with aversion to the Convention arguably at its most pronounced in the EU. ${ }^{3}$ It is the only one of the ten core instruments not to have been ratified by any of the $28 \mathrm{EU}$ Member States, despite the support for ratification expressed at the national level by NGOs and individual political parties and at the Eu level by the European Parliament and bodies such as the European Economic and Social Committee. While the Convention has been ratified by a number of important migrant-destination countries such as Argentina, Libya, Mexico and Turkey, ratification is more common amongst origin countries like

1 For the full list see the website of the онснR: http://www.ohchr.org/EN/ProfessionalInterest/ Pages/CoreInstruments.aspx.

2 For the full list of States Parties and signatories to the Convention see the UN Treaty Collection, available online at https://treaties.un.org/Pages/ViewDetails.aspx?src=TREATY\& mtdsg_no=IV-13\&chapter $=4 \&$ lang=en.

3 There is of course also a noticeable antipathy towards the ICMW in the Us, Canada and Australia, all developed countries with rich histories of immigration. 
Algeria, Morocco and the Philippines who are keen to secure protection for their foreign-based nationals. ${ }^{4}$

The article will begin by briefly sketching the factors which gave rise to the ICMW, before providing a general overview of the structure and content of the Convention and the obstacles to its ratification in the $\mathrm{EU}$. It will then discuss EU migration law and policy, its compatibility with the ICMW and the attitude evinced at EU level towards the Convention. The substantive section of the article deals with the strikingly high number of recommendations made to EU Member States to ratify the ICMW during the Universal Periodic Review (UPR), one of the UN Human Rights Council's flagship innovations. Despite the general trend of EU Member States to 'reject' recommendations to ratify, and the various anomalies revealed by such recommendations, we will suggest that the UPR may in fact hold the potential to significantly advance the issue of ratification by EU Member States.

The Convention

\subsection{Background to the Convention}

During the two decades following the adoption of the UDHR in 1948, the issue of migrants' rights was conspicuous by its almost complete absence from UN human rights discussion. ${ }^{5}$ The gaps in the protection of migrants' rights in international human rights law were exposed by Idi Amin's expulsion of Uganda's non-citizen Asian population in 1972, an event which led the UN Commission on Human Rights to seek clarification of the application of international human rights law to non-citizens. ${ }^{6}$ This yielded a substantive legal study in 1980 which found that the only effective form of protection for migrants was the diplomatic protection offered by their State of nationality and recommended that a legally binding treaty on migrants' rights should be preceded by the adoption by the UN of a Declaration balancing the rights attached to

4 The origin-destination binary is not a mutually exclusive system of categorisation. Given the fluid nature of migration flows, States can go from being primarily an origin country to one of destination, and vice versa. Few would argue with the statement that States like Mexico and Morocco today play important roles simultaneously as countries of origin, transit and destination.

5 S. Grant (2011), 'The Recognition of Migrants' Rights within the Un Human Rights System: the first sixty years', in: M. Dembour and T. Kelly (eds), Are Human Rights for Migrants?, Abingdon: Routledge, pp. 25-47, at p. 32.

6 Ibid., pp. 33-34. 
States' sovereignty with the rights of all individuals. ${ }^{7}$ The Declaration on the Human Rights of Individuals who are not Citizens of the Country in which they Live, adopted in 1985, was, by its very nature, without binding legal force, but is noteworthy for recognising not only the rights of those who were lawfully present in a host State but also the rights of irregular migrants. ${ }^{8}$

Shortly after Idi Amin's expulsion of 60000 non-citizens from Uganda in 1972, the oil crisis created an economic downturn which gave rise to an increase in irregular migration and fuelled concerns about the abuse and exploitation to which migrants in a depressed economic climate were particularly vulnerable. ${ }^{9}$ It was a desire to ameliorate this newly migrant-hostile environment that partly motivated Mexico and Morocco, two important countries of origin for international migrant workers, to begin a campaign in the mid-1970s for the elaboration of a UN convention on the protection of migrants' human rights. When the UN General Assembly adopted a resolution in 1979 establishing a working group for the drafting of a Convention on migrants' rights, ${ }^{10}$ it was Mexico which took the chair.

One further factor is worth highlighting as contributing to the elaboration of the ICMW. The ILO had a constitutional mandate for codifying standards concerning migrant workers, ${ }^{11}$ and the role of ILO Conventions in the governance of labour migration and the protection of migrant workers is exemplified by the Convention concerning Migration for Employment (Revised), 1949 (No. 97) and the Convention concerning Migrations in Abusive Conditions and the Promotion of Equality of Opportunity and Treatment of Migrant Workers, 1975 (No. 143). Both of these Conventions preceded the adoption of the ICMW and

D. Elles, International Provisions Protecting the Human Rights of Non Citizens, Un Doc. E/ CN.4/Sub.2/392/Rev.1, cited in Grant, supra note 5, pp. 34-35.

8 It is worth pointing out that the UN neglect of migrants' rights during the period under discussion is not reflected in the activity of the ILO. This is evidenced by, for example, the ILO Migration for Employment Convention (Revised), 1949 (No. 97) and the ILO Migrant Workers (Supplementary Provisions) Convention, 1975 (No. 143), the latter being an example of a binding legal instrument which required States Parties to respect the basic human rights of all migrant workers.

G. Battistella (2009), 'Migration and Human Rights: The Uneasy but Essential Relationship', in: P. de Guchteneire, A. Pécoud and R. Cholewinski (eds), Migration and Human Rights: The United Nations Convention on Migrant Workers' Rights, Cambridge: Cambridge University Press, pp. 47-69, at p. 51.

$10 \quad$ UN General Assembly Resolution 34/172 of 17 December 1979.

11 See Preamble to the Constitution of the ILO, Recital 2. 
have been ratified by a number of EU Member States. ${ }^{12}$ Many States, however, were unhappy with Convention No. $143^{13}$ and other ILO treaties in the field of labour migration, with the organisation itself being viewed as structured to the advantage of developed countries and too susceptible to the influence of trade unions. ${ }^{14} \mathrm{~A}$ further factor making the UN a more attractive venue than the ILO was the fact that UN conventions, unlike ILO treaties, can accommodate some State concerns by allowing ratifying States to insert reservations on certain provisions, essentially relieving States of the obligation to comply with treaty provisions on which they make reservations. ${ }^{15}$ Finally, developing countries sought to take advantage of the oil crisis to promote a new economic order, and the UN was seen as a more suitable venue for such a venture than the ILO. ${ }^{16}$

But while the UN was chosen as the forum for the elaboration of a convention on the protection of migrant workers, it is worth noting that the ILO was not completely sidelined. ILO representatives provided input during the drafting process and the Preamble to the ICMW makes explicit reference to the principles contained in the ILO's conventions, as well as expressly acknowledging the organisation's experience and expertise in matters related to migrant workers and their families. Finally, representatives of the ILO participate in a consultative capacity in the meetings of the Committee on Migrant Workers, ${ }^{17}$ the treaty body responsible for monitoring the compliance of States Parties with the ICMW.

$125 \mathrm{EU}$ Member States have ratified Convention No. 143, while 10 have ratified Convention No. 97. For more detailed information see http://www.ilo.org/dyn/normlex/en/f?p= 1000:12001:0::NO:::

13 See R. Cholewinski (1997), Migrant Workers in International Human Rights Law: Their Protection in Countries of Employment, Oxford: Clarendon Press, p. 141.

14 See E. MacDonald and R. Cholewinski (2007), The Migrant Workers Convention in Europe: Obstacles to the Ratification of the International Convention on the Protection of the Rights of All Migrant Workers and Members of their Families: EU/EEA Perspectives, Paris: UNEsCO, pp. 21-22 and the literature cited therein.

15 It is worth noting, however, that some ILO Conventions do allow States Parties some flexibility. Convention No. 143, for example, is divided into two parts and gives States Parties the possibility to ratify one part or the other.

16 P. de Guchteneire and A. Pécoud (2009), 'Introduction: the UN Convention on Migrant Workers' Rights', in: P. de Guchteneire, A. Pécoud and R. Cholewinski (eds), Migration and Human Rights: The United Nations Convention on Migrant Workers'Rights, Cambridge: Cambridge University Press, pp. 1-44, at p. 7.

17 Article 74 of the ICMw. See also C. Edelenbos (2009), 'Committee on Migrant Workers and Implementation of the ICRMw', in: P. de Guchteneire, A. Pécoud and R. Cholewinski (eds), Migration and Human Rights: The United Nations Convention on Migrant Workers' Rights, Cambridge: Cambridge University Press, pp. 100-121, at p. 115. 
In any discussion concerning the ICMW and the EU, it is important to underline the fact that the Convention may be seen as a European text. This may come as a surprising assertion, given that European States were unenthusiastic about the idea of a UN convention on migrant workers' rights to begin with, viewing UN involvement in this field as inappropriate in light of the ILO's existing instruments and established role in the field of labour standards. ${ }^{18}$ Indeed, disdain for a new UN instrument was also evident when western European States rejected the first draft of the Convention submitted to the General Assembly working group as a 'blank cheque for continued illegal migration.'19 Subsequently, however, a number of Mediterranean and Scandinavian countries - Finland, Greece, Italy, Portugal, Spain, Sweden and later Norway came together in an informal group known as MESCA which provided the working group with an alternative outline of the Convention which became the definitive structure. This led one expert who participated in the drafting process to characterise the ICMW as 'fundamentally a European text, although modified by the long negotiation process. ${ }^{20}$

The 'long negotiation process' stretched from 1980 to 1990 and resulted from a combination of factors including frequent alterations in the composition of the working group, the need for these moveable delegates to consult with their governments and the changes in migration flows over the course of the decade which occasioned shifts in migration management and government attitudes towards international agreements. ${ }^{21}$ By the time the UN General Assembly finally adopted the ICMW on 18 December 1990, about half of the UN Member States had participated at one point or another in the drafting process. $^{22}$ The finished product represented an attempt to balance a recognition of the human rights of migrants with the rights of States to control the admission and residence of non-citizens. But even before the product was finished, the support it enjoyed was limited, with a number of important destination countries including Germany, the USA and Australia indicating at the time of drafting that they were unlikely to ratify. ${ }^{23}$ This was particularly ominous when

18 Grant, supra note 5, p. 35 .

19 R. Böhning, 'The ILO and the New UN Convention on Migrant Workers: The Past and Future', 25 International Migration Review (1991) 698-709, at p. 701.

20 Battistella, supra note 9, p. 55. The 'long negotiation process' of the ICMW is not, contrary to popular belief, the longest negotiation process involving core international human rights instruments. Both the ICCPR and ICESCR were adopted in 1966 after 14 years of negotiations.

21 Battistella, supra note 9, p. 56.

22 De Guchteneire and Pécoud, supra note 16, p. 8.

23 Cholewinski, supra note 13, p. 203. 
one considers that the drafting process was marked by a broad consensus as to the entitlement of all migrants, regardless of status, to the protection of their rights, ${ }^{24}$ and that delegates representing migrant-destination States had endeavoured to ensure that the Convention was acceptable to their governments for ratification. ${ }^{25}$

\subsection{The Structure and Content of the Convention: A General Outline}

Broadly speaking, the overall structure and underlying rationale of the ICMW is similar to that of the other core international human rights treaties. Like the CRPD, the CEDAW and the CRC, the ICMW takes the rights set out in the International Bill of Human Rights, namely the UDHR, the ICCPR and the ICESCR, and codifies and elaborates on them in relation to a particularly vulnerable category of persons, in this case migrant workers and members of their families. ${ }^{26}$ With 93 articles, divided into 9 Parts, the ICMW is the longest of the ten core international human rights instruments. It is therefore not surprising that the Convention is a comprehensive document, covering the entire migration process from pre-departure in the country of origin, through travel in countries of transit, to entry and residence in the destination State and return to the country of origin.

Part I sets out the definitions of the terms used in the Convention while Part II, a single Article, contains the non-discrimination clause. Part III, consisting of Articles 8-35, is the longest and most controversial section of the Convention and is sometimes cited as an obstacle to ratification. It sets out the rights to be enjoyed by all migrants, regardless of their status. These include civil and political rights found in the ICCPR such as the right to life; freedom from torture; freedom from slavery; freedom from arbitrary arrest and detention; and freedom of expression. Part III also specifies the enjoyment by all migrants of a number of economic and social rights found in the ICESCR such as the rights to join trade unions; to medical care; and to education for their children.

24 Grant, supra note 5, p. 36.

25 Battistella, supra note 9, p. $5^{8}$.

26 More detailed analysis of the provisions of the Convention can be found in, e.g., Cholewinski, supra note 13, chapter 4; L. Bosniak, 'Human Rights, State Sovereignty, and the Protection of Undocumented Migrants under the International Migrant Workers Convention', 25 International Migration Review (1991) 737-770; K. Touzenis and A. Sironi, Current Challenges in the Implementation of the UN International Convention on the Protection of the Rights of All Migrant Workers and Members of Their Families, Brussels: European Parliament, 2013, available online at http://www.europarl.europa.eu/RegData/ etudes/etudes/join/2013/433715/EXPO-DROI_ET(2013)433715_EN.pdf. 
Part III also elaborates upon a number of rights which are of particular importance for migrant workers and members of their families. States are obliged to inform migrants of their right to the consular protection and assistance of their States of origin when any right set out in the Convention is impaired, and particularly in the event of expulsion. Furthermore, Article 22 of the Convention prohibits collective expulsion and provides that a migrant may only be expelled on the basis of a decision taken by the competent authority in accordance with law following an individualised assessment of the case. Article 22 affords a particularly robust catalogue of safeguards to migrants who are to be deported, going beyond the protection provided in instruments such as the ICCPR and regional measures such as the EU Returns Directive.

States are also obliged to ensure, in so far as practicable, that migrant workers who are detained in a State of transit or employment for violation of provisions relating to migration shall be held separately from persons who have been convicted or detained pending trial. The Convention includes a prohibition on unlawful confiscation or destruction of a migrant's personal documents and recognises the right of migrants to transfer their earnings and savings upon the termination of their stay in the State of employment.

The provisions set out in Part IV impose obligations on States Parties to the Convention only vis-à-vis lawfully resident migrants. These include the right of migrants to form associations and trade unions for the promotion and protection of their economic, social, cultural and other interests; ${ }^{27}$ the right to move freely and choose residence in the State of employment; and the right of migrant workers to family reunification, though in this regard States Parties are only obliged to 'take measures that they deem appropriate and that fall within their competence'.

27 It is important to note in this regard that the Committee on Migrant Workers has recently drawn attention to the fact that while the right codified in Article 40 ICMW to form associations and trade unions in the State of employment is limited to migrants in a documented or regular situation, other instruments including the ICCPR, the ICESCR and ILO Freedom of Association and Protection of the Right to Organise Convention, 1948 (No. 87), confer this right on all persons, irrespective of migration status. In this regard, the Committee recommends that a State's obligation under the ICMW be read in light of 'the core human rights treaties and other relevant international instruments to which it is a party. Although separate and freestanding, these treaties are complementary and mutually reinforcing.' See General Comment No. 2 on the rights of migrant workers in an irregular situation and members of their families, paras 7-12, CMW/C/GC/2 (28 August 2013), available online at http://tbinternet.ohchr.org/_layouts/treatybodyexternal/TBSearch.aspx?L ang=en\&TreatyID=7\&DocTypeID=11. 
Migrant-specific protections codified in Part IV include the guidance that States, when considering whether to expel a migrant worker or family member, should take account 'of humanitarian considerations and of the length of time that the person concerned has already resided in the State of employment'. Furthermore, lawfully present migrants are granted the right to transfer their earnings and savings, with States under a corresponding obligation to take appropriate measures to facilitate such transfers.

Part v deals with and sometimes qualifies the rights of migrant workers in specific categories of employment, while Part vi sets out the ways in which States Parties should 'co-operate with a view to promoting sound, equitable and humane conditions in connection with international migration of workers and members of their families'. This Part imposes obligations mainly, though by no means exclusively, on destination States. The requirements imposed by Part VI include exchange of information between the competent authorities in States Parties to the Convention as well as collaboration between States with a view to 'preventing and eliminating illegal or clandestine movements and employment of migrant workers in an irregular situation'. Underscoring the Convention's distinction between regular and irregular migrants, Part VI requires States Parties to co-operate in relation to the return home of the former 'with a view to promoting adequate economic conditions for their resettlement and to facilitating their durable social and cultural reintegration in the State of origin'.

Part viI deals with the establishment and operation of the Committee on Migrant Workers, the body responsible for monitoring States Parties' compliance with the Convention through reviewing and commenting on periodic reports from States. These reports contain information on the measures undertaken to give effect to the provisions of the Convention as well as any difficulties affecting implementation of the Convention and details on migration flows in the reporting State. The Committee, currently composed of 14 independent experts, held its first session in March 2004. Part VII empowers the Committee to receive complaints against States Parties from individuals as well as from other States Parties, subject to the express acceptance of ten States Parties of this power. So far, however, just two States have accepted the individual complaint mechanism and just one has accepted the inter-state complaint procedure.

Part VIII contains 'general provisions' which require States Parties to provide an effective remedy to any individual whose rights under the Convention are impaired and to take the legislative and other measures necessary to give effect to the Convention. At the same time, however, States are reassured that nothing in the Convention will interfere with their right to establish the 
criteria governing admission of migrants. Part IX sets out the 'final provisions' which include the right of States to make reservations to specific obligations when ratifying, with the obvious prohibition firstly on lodging a reservation on the entirety of any of the 9 Parts of the Convention and, secondly, any other reservation which would be incompatible with the object and purpose of the Convention.

\subsection{Obstacles to Ratification in the EU}

Investigations into the non-ratification of the Convention in the $\mathrm{EU}$ have pointed to a lack of awareness of the Convention as a significant problem ${ }^{28}$ and, in addition, have yielded a wide variety of State objections to the instrument. ${ }^{29}$ These include the financial and administrative burden that ratification would impose on a State; the incompatibility of certain provisions of the Convention with a State's legal and constitutional framework; the redundancy of the Convention in light of the protection of migrants' rights provided by national legislation and the regional and international instruments to which a State is party; and the competence of the EU in migration matters which, it is claimed, precludes ratification of the Convention by any one individual EU Member State.

Another oft-rehearsed objection is that ratification of the Convention would result in a significant encroachment on the sovereignty of States, tying States' hands when it comes to deciding who may enter their territory. It is important to note in this regard the Article 79 of the Convention provides explicitly that nothing in the document shall affect the right of each State Party 'to establish the criteria governing admission of migrant workers and members of their families.' Thus while the Convention is largely concerned with migrants' rights, it cannot be interpreted as in any way usurping the power of States Parties to regulate the admission of non-nationals.

The potentially most fatal accusation levelled at the Convention is that by failing to distinguish between lawfully and unlawfully present migrants ${ }^{30}$ it

28 It is difficult to resist the impression that there is a certain reticence on the part of the UN itself vis-à-vis promotion and awareness-raising of the Convention. This is evidenced, albeit anecdotally, by the fact that the ICMW is the only one of the ten core international human rights instruments for which there is no material in the UN historic archives of the Audiovisual Library of International Law. See http://legal.un.org/avl/ha/humanrights .html.

29 See, for example, MacDonald and Cholewinski, supra note 14.

30 Most recently and egregiously repeated in para. 13, Council of the European Union, Conclusions of the Council and of the Representatives of Governments of the Member States meeting within the Council on the 2013 UN High-Level Dialogue on Migration and 
incentivises irregular migration. This is also the laziest charge, as the most cursory reading of the text makes clear that only certain fundamental rights, outlined in Part III of the text, are accorded to all migrants. The Convention thus makes a very clear distinction between these two categories of migrants.

The wealth of foregoing ostensible obstacles notwithstanding, studies undertaken suggest that the principal barrier to ratification of the Convention is a lack of political will. ${ }^{31}$ With many perceived obstacles a result of misconception or misrepresentation, there are few real legal obstacles to ratification which, in any case, could be neatly dealt with by means of a reservation or minor changes to domestic legislation. The prospects of overcoming this lack of political will through peer pressure and related civil society advocacy will be examined in Section 4 below.

Eu Migration Law and the Convention

\subsection{The EU Migration Law Landscape}

As mentioned, one of the reasons EU Member States sometimes advance to justify non-ratification of the ICMW is the competence of the EU in the field of migration. The claim is that unilateral ratification is a non-starter in light of this competence and that, instead, a coordinated approach to ratification is required at the Eu level. But does such a claim withstand scrutiny? In seeking to answer this question this Section will examine the evolving role and competence of the EU in the field of migration law and policy, how the Convention may or may not fit within the framework of such law and policy and the role that the EU could play in preventing or promoting ratification amongst its Member States and further afield.

It is worth noting that discussion of a common EU migration policy revolves around a policy focused largely on non-Eu citizens, so-called third-country nationals (TCNs). The key legal development in the slow construction of a common EU migration policy was the entry into force of the Treaty of Amsterdam in 1999. The Treaty brought the Schengen acquis within the remit

Development and on broadening the development-migration nexus, Brussels, 19 July 2013, available online at http://register.consilium.europa.eu/doc/srv?l=EN\&f=ST\%2012415\%20 2013\%20INIT.

31 Touzenis and Sironi, supra note 26, p. 4; M. D’Auchamp (2011), Rights of Migrant Workers in Europe, Brussels: онснR Regional Office for Europe, p. 6, available online at http://www .europe.ohchr.org/Documents/Publications/Migrant_Workers.pdf. 
of the $\mathrm{EU}^{32}$ and conferred (shared) competence on the $\mathrm{EU}$ over asylum and migration by transferring these matters to Title IV EC, commonly known as the Community Pillar. The aim of Title IV was to establish progressively an area of freedom, security and justice (AFSJ) $)^{33}$ and it facilitated development of a common migration policy by making a number of areas, including irregular migration, subject to measures adopted by the Council. ${ }^{34}$

EU competence over asylum and migration matters was, however, subject for a transitional period of five years to a number of limitations which significantly constrained the development of a common EU policy and perpetuated the prioritisation of migration control over respect for the rights of migrants which had characterised intergovernmental cooperation in this field prior to the Treaty of Amsterdam. ${ }^{35}$ As well as the opt-outs secured by Ireland, the UK and Denmark, the jurisdiction of the CJEU was restricted to consideration of preliminary references from national courts or tribunals of final instance, the roles of the Commission and the European Parliament were circumscribed and the Council, in adopting measures under Title IV, was required to act unanimously.

The practical realisation of the mandate in the Treaty of Amsterdam to create an AFSJ was discussed in two important policy documents, namely the Vienna Action Plan ${ }^{36}$ and the Tampere Conclusions. ${ }^{37}$ The Tampere Conclusions, the first multi-annual programme for creating an AFSJ, acknowledged that the freedom which Union citizens take for granted should not be regarded as the exclusive preserve of those citizens, its very existence acting 'as a draw to many others world-wide...' and noted the need to ensure fair treatment of TCN s, but such treatment was discussed in the context of lawfully present TCN s. Indeed both the Vienna Action Plan and the Tampere Conclusions evinced a preoccupation with prevention and reduction of irregular migration which was to be achieved through, inter alia, a coherent EU policy on

\footnotetext{
32 Protocol No. 2 integrating the Schengen acquis into the framework of the European Union, OJ 1997, C 340/93.

33 Article 61 of the then Ec Treaty.

34 Article $63(3)(\mathrm{b})$ of the then Ec Treaty.

35 See generally R. Cholewinski (2012), 'The EU Acquis on Irregular Migration Ten Years On: Still Reinforcing Security at the Expense of Rights?', in: E. Guild and P. Minderhoud (eds), The First Decade of EU Migration and Asylum Law, Leiden: Martinus Nijhoff, pp. 127-178.

36 Action Plan of the Council and the Commission on how best to implement the provisions of the Treaty of Amsterdam on an area of freedom, security and justice, adopted by the JHA Council on 3 Dec. 1998, OJ 1999, C 19/1.

37 Presidency Conclusions, Tampere European Council, 15-16 October 1999, Bulletin EU 10-1999.
} 
readmission and return, ${ }^{38}$ further harmonisation of Member States' laws on carriers' liability ${ }^{39}$ and closer cooperation between Member States' border control services. ${ }^{40}$

It is therefore perhaps not surprising that the common migration policy which has developed since 1999 within the framework of the Tampere Conclusions and subsequent multi-annual programmes has been criticised for treating irregular migration largely as a security issue, with insufficient attention paid to irregular migrants' rights, ${ }^{41}$ and for a less than full-blooded vindication of the human rights of lawfully resident TCN s. ${ }^{42}$ The security and law enforcement approach to irregular migration is strikingly exemplified by the adoption by the JHA Council in 2010 of 29 measures to reinforce protection of the external borders and address irregular migration. ${ }^{43}$

The entry into force of the Treaty of Lisbon in December 2009 has, however, ushered in a number of important changes which have both accelerated movement towards a common migration policy ${ }^{44}$ and created a more migrant-friendly human rights environment. While the European Council in its third multi-annual programme, the Stockholm Programme, ${ }^{45}$ called for the Lisbon Treaty to be exploited to strengthen the AFsJ for the benefit of Union citizens, ${ }^{46}$ the Treaty also offers opportunities to strengthen the same area for the benefit of migrants.

38 Vienna Action Plan, supra note 36, para. 36(c)(ii).

39 Vienna Action Plan, supra note 36, para. 36(d)(iv).

$40 \quad$ Tampere Conclusions, supra note 37, para. 24.

41 Cholewinski, supra note 35, p. 128.

42 The extent to which the goal of fair treatment of lawfully-resident TCNs has been realised is itself questionable. See generally, L. Halleskov Storgaard (2012), 'The LongTerm Residents Directive: A Fulfilment of the Tampere Objective of Near-Equality?', in: E. Guild and P. Minderhoud (eds), The First Decade of EU Migration and Asylum Law, Leiden: Martinus Nijhoff, pp. 299-327.

43 Commission Staff Working Document on the fulfilment of the 29 measures for reinforcing the protection of the external borders and combating illegal immigration adopted at the Justice and Home Affairs Council meeting, held on Brussels on 25 and 26 February 2010, SEC (2010) 1480 final, 26 November 2010.

44 See, for example, D. Acosta Arcarazo and A. Geddes, 'The Development, Application and Implications of an EU Rule of Law in the Area of Migration Policy', $5^{1}$ Journal of Common Market Studies (2013) 179-193; S. Carrera, M. De Somer and B. Petkova (2012), The Court of Justice of the European Union as a Fundamental Rights Tribunal: Challenges for the Effective Delivery of Fundamental Rights in the Area of Freedom, Security and Justice, Brussels: CE PS.

45 The Stockholm Programme - An Open and Secure Europe serving and protecting Citizens (2010/C 115/01) OJ C 115, 4.5.2010.

46 Ibid., p. 4. 
Indeed, a number of benefits have already accrued to migrants as a result of the important institutional and legislative changes wrought by the Treaty of Lisbon. The CJEU is now empowered to give preliminary rulings to any national court or tribunal on the validity of acts in the AFSJ by EU institutions, ${ }^{47}$ the Council is no longer required to act unanimously this field, the ordinary legislative procedure has been extended beyond measures concerning asylum and borders to include legal and labour migration, ${ }^{48}$ transforming the European Parliament into co-legislator, the $\mathrm{EU}$ will accede to the $\mathrm{ECHR}^{49}$ and the Charter of Fundamental Rights has been made legally binding on the EU. ${ }^{50}$

These changes have been characterised as representing a move away from intergovernmentalism toward Europeanisation in the $\mathrm{AFSJ},{ }^{51}$ with one consequence being that the JHA Council may no longer unilaterally decide policy priorities and legislative outputs. ${ }^{52}$ They are certainly changes which increase the chances of a rights-based approach being taken to legislation in the field of migration and perhaps also increase the chances that the ICMW will receive serious attention.

The post-Lisbon competence of all national judges to seek preliminary rulings from the CJEU, ${ }^{53}$ coupled with the urgent procedure for preliminary rulings agreed in $2008,{ }^{54}$ has already had a significant impact in the field of irregular migration and suggests that the paucity of questions referred by national judges on migration matters prior to the entry into force of the Treaty

47 Article 19 TEU and Article 267 TFEU, Consolidated Versions of the TEU and the TFEU OJ 2010/C 83/01, 30 March 2010.

48 Articles 77-79 TFEU, Consolidated Versions of the TEU and the TFEU OJ 2010/C 83/01, 30 March 2010.

49 Article 6(2) TEU, Consolidated Versions of the TEU and the TFEU OJ 2010/C 83/01, 30 March 2010.

$5^{\circ}$ Article 6(1) TEU, Consolidated Versions of the TEU and the TFEU OJ 2010/C 83/01, 30 March 2010.

$5^{1}$ S. Carrera (2012), 'The Impact of the Treaty of Lisbon over EU Policies on Migration, Asylum and Borders: The Struggles over the Ownership of the Stockholm Programme', in: E. Guild and P. Minderhoud (eds), The First Decade of EU Migration and Asylum Law, Leiden: Martinus Nijhof, pp. 227-254, at p. 252.

$52 \quad$ Ibid.

53 Article 267 TFEU, Consolidated Versions of the TEU and the TFEU OJ 2010/C 83/01, 30 March 2010.

54 Council Decision of 20 December 2007 amending the Protocol on the Statute of the Court of Justice, OJ [2008] L 24/42, and amendments to the Rules of Procedure of the Court of Justice adopted by the Court on 15 January 2008, oJ [2008] L 24/39. The Council called on the Court to apply the urgent preliminary ruling procedure in situations involving deprivation of liberty, Statement OJ [2008] L24/44. 
of Lisbon may be a trend that has been consigned to the past. ${ }^{55}$ The combined total of such questions in the five years pre-Lisbon was $6,{ }^{56}$ with almost the same number again being referred in the first year after the entry into force of the Treaty, ${ }^{57}$ and 17 preliminary references concerning migration matters being made in 2011. ${ }^{58}$ One of the cases arising from these preliminary references, El Dridi, is a good illustration both of how the CJEU constrains domestic migration law to the benefit of migrants and how the changes introduced by the Lisbon Treaty are facilitating ever greater movement toward a common EU migration policy. In El Dridi the CJEU held that Member States may not provide for a custodial sentence solely on the ground that an irregularly staying TCN has not complied with an order to leave the national territory within the time limit specified in the order. ${ }^{59}$

Another impact of the Treaty of Lisbon, that of making a co-legislator of the comparatively migrant-friendly European Parliament, cannot but augur well for the ICMW. While the Parliament was widely criticised for its endorsement of the Returns Directive, its involvement in the legislative process did ensure some important safeguards against expulsion ${ }^{60}$ and it has since shown its willingness to take an independent stance where it views EU measures to be lacking from a human rights perspective. ${ }^{61}$ Indeed, the involvement of the Parliament in the negotiations over the Seasonal Workers Directive ${ }^{62}$ ensured the inclusion of important safeguards from exploitation for seasonal workers as well as equal treatment with nationals in a number of areas. ${ }^{63}$

55 For more on this issue see Acosta and Geddes, supra note 45.

56 Ibid., p. 180.

57 Ibid., p. 181.

58 Ibid.

59 C-61/11 PPU, El Dridi, judgment of 28 April 2011, para. 58.

6o A. Baldaccini, 'The Return and Removal of Irregular Migrants under EU Law: An Analysis of the Returns Directive', 11 European Journal of Migration and Law (2009) 1-17, at p. 2.

61 R. Clancy, EU rejects single permit draft as potentially violating fundamental rights, 22 December 2010, Expatforum.com, available online at http://www.expatforum.com/ articles/eu-rejects-single-permit-draft-as-potentially-violating-fundamental-rights.html.

62 Directive 2014/36/EU of the European Parliament and of the Council of 26 February 2014 on the conditions of entry and stay of third-country nationals for the purpose of employment as seasonal workers [2014] OJ L94/375.

63 J. Fudge and P. Herzfeld Olsson, 'The Eu Seasonal Workers Directive: When Immigration Controls Meet Labour Rights', 16 European Journal of Migration and Law (2014) 439-466. 
3.1.1 The Charter and EU accession to the ECH R

The Charter of Fundamental rights, adopted by the Parliament, Council and Commission in 2000 and proclaimed in 2007, gained binding legal effect with the entry into force of the Lisbon Treaty in December $2009 .{ }^{64}$ The Charter has been described as a Bill of Rights for EU citizens which has transformed the relationship between the individual and the State as it provides a range of rights and entitlements while being neither nation-state constitution nor international human rights treaty. ${ }^{65}$

The rights codified in the Charter are not, however, the exclusive preserve of EU citizens. While there are some limitations in the Charter concerning the rights of migrants in an irregular situation, ${ }^{66}$ only one of the Charter's seven Chapters, namely Chapter V on Citizens' Rights, contains provisions with a citizenship limitation and even then that Chapter's provision on the right to good administration is applicable to all persons, and not just citizens. ${ }^{67}$

The scope of the Charter is not the only feature of the document which vests it with the potential to make a significant impact in the field of migration. Although the Charter is not intended to expand EU competence or the scope of EU law, ${ }^{68}$ it has been characterised by the Presidents of the ECtHR and the CJEUas the reference text and starting point for the CJEU's assessment of the rights contained therein, ${ }^{69}$ and it recognises a number of migration-related rights not included in the ECHR such as the right to asylum, ${ }^{70}$ the rights of the child ${ }^{71}$ and the right to an effective remedy against all decisions of national authorities applying EU migration measures. ${ }^{72}$ The Charter thus reveals the extent to which many aspects of EU migration law are now rights-based and no longer discretionary. ${ }^{73}$

64 Article 6(1) TEU, Consolidated Versions of the TEU and the TFEU OJ 2010/C 83/01, 30 March 2010.

65 E. Guild, The European Union after the Treaty of Lisbon: Fundamental Rights and EU Citizenship, Brussels: CEPS 2010, p. 1.

66 For example Article 34 of the Charter on social security and social assistance.

67 Article 41 of the Charter.

68 Article $51(2)$ of the Charter.

69 Joint Communication from Presidents Costa and Skouris, press release no. 75 issued by the Registrar of the ECtHR on 27 January 2011.

70 Article 18 of the Charter.

71 Article 24 of the Charter.

72 Article 47 of the Charter.

73 S. Peers (2012), 'Immigration, Asylum and the European Union Charter of Fundamental Rights', in: E. Guild and P. Minderhoud (eds), The First Decade of EU Migration and Asylum Law, Leiden: Martinus Nijhoff, pp. 437-468, at p. 468. 
The Charter, however, sets out a minimum level of rights protection and explicitly permits the EU and individual Member States to provide greater rights protections than those contained in the Charter and the ECHR. ${ }^{74}$ Where the Charter sets out rights which correspond to rights guaranteed by the ECHR, the meaning and scope of such rights are to be the same as those laid down by the ECHR. ${ }^{75}$ Thus, for example, Article 7 of the Charter which corresponds to Article 8 ECHR is to be interpreted and applied in line with Article 8 principles and jurisprudence.

While the CJEU has already held that the ECHR is an 'integral part of the general principles of law observance of which the Court ensures, ${ }^{76}$ and the Charter suggests the use of the ECHR as a minimum standard of protection, ${ }^{77}$ the Treaty of Lisbon has further strengthened the position of the ECHR in the EU legal order by obliging the EU to accede to the Convention. ${ }^{78}$ This will essentially put the EU in the same position as its Member States vis-à-vis the ECHR, with the rights enshrined therein becoming binding on the $\mathrm{EU}$ and its institutions and individuals enjoying the right to bring a complaint about infringement of ECHR rights by the EU before the ECtHR. ${ }^{79}$ The status accorded to ECHR jurisprudence by the Charter and the obligation on the EU to accede to the ECHR significantly enhances the impact and potential of the important body of case law concerning migrants' rights developed by the ECtHR over the past 25 years.

It thus seems safe to observe that the post-Lisbon landscape offers a comparatively promising vista from the perspective of migrants' rights.

\subsection{EU Migration Law and the IcMW}

The EU's common migration policy and the UN's ICMW have been described as being animated by the same dual concern with, on the one hand, ensuring fair treatment of migrants and, on the other hand, managing migration flows. ${ }^{80}$

\footnotetext{
74 Articles $52(3)$ and 53 of the Charter.

75 Article $52(3)$ of the Charter.

76 C-540/o3, European Parliament v Council, ECR (2006) I-5769 (judgment of 27 June 2006).

77 Article $5^{2}(3)$ of the Charter.

78 Article 6(2) TEU, Consolidated Versions of the TEU and the TFEU OJ 2010/C 83/01, 30 March 2010.

79 Council of Europe, Accession by the European Union to the European Convention on Human Rights: Answers to Frequently Asked Questions, 30 April 2013, available online at http://www.coe.int/t/dghl/standardsetting/hrpolicy/accession/Accession_documents/ EU_accession-QA_updated_2013_E.pdf.

8o E. MacDonald and R. Cholewinski (2009), 'The ICRMw and the European Union', in: P. de Guchteneire, A. Pécoud and R. Cholewinski (eds), Migration and Human Rights: The
} 
The preoccupation of the ICMW with codifying the rights of migrants stands in sharp contrast with the focus of EU activity in the migration field on codifying rules for the regulation of TCNs' entry to and movement in the EU. ${ }^{81}$ But does this divergence of priorities mean that the ICMW is irretrievably incompatible with EU migration law and policy, thereby precluding ratification by EU Member States?

There are clearly aspects of EU migration law which fall short of ICMW standards. One striking instance of this divergence is the principle of equality of treatment between migrants and citizens which, so central to the ICMW, ${ }^{82}$ has been considerably attenuated in the development of a common EU migration policy. ${ }^{83}$ Article 11 of the Long-Term Residence Directive, ${ }^{84}$ for example, specifies a number of areas such as education and employment where longterm resident TCNs should enjoy equal treatment with citizens and also provides for the restriction of equality of treatment to certain core benefits. Article 11 of the Long-Term Residence Directive finds its equivalent in Article 45 of the ICMW which is far more migrant-friendly. The equal treatment principle in Article 45 is not only less subject to restrictions, but Article 45 applies to all lawfully resident TCNs, and not just those who are long-term residents.

At the same time, however, there are aspects of EU migration law which are more generous than what would be required by the ICMW. ${ }^{85}$ The obligation to facilitate family reunification imposed on Member States by the Family Reunification Directive ${ }^{86}$ goes far beyond the minimum required by Article 44 of the Convention. Similarly, Article 35 of the Charter recognises the right of everyone to preventive health care and medical treatment, while Article 28 of the Convention requires that irregular migrants have access only to emergency medical care.

Finally, it would seem that there are also areas where the Convention chimes concordantly with EU migration law. Article 69 of the ICMW requires

\footnotetext{
United Nations Convention on Migrant Workers' Rights, Cambridge: Cambridge University Press, pp. 360-392, at p. 375 .

81 Ibid.

82 See Articles 18, 25, 28, 30, 43, 44, 45, 54 and 55 of the Convention.

83 For more detailed discussion of the dilution of the equal treatment principle in this context, see MacDonald and Cholewinski, supra note 81, pp. 373-377.

84 Council Directive 2003/109/EC of 25 November 2003 concerning the status of thirdcountry nationals who are long-term residents, oJ L 16, 23 January 2004, pp. 44-53.

85 For more detail on this, see Touzenis and Sironi, supra note 26, pp. 14-19.

86 Council Directive 2003/86/EC reunification of 22 September 2003 on the right to family reunification, OJ L 251, 3 October 2003.
} 
States Parties to take appropriate measures to eliminate situations where migrant workers and members of their families are irregularly present. While this provision has been read by some as potentially imposing a regularisation obligation on States, ${ }^{87}$ it arguably goes no further than the requirement of the Returns Directive to expel or regularise unlawfully present migrants. The aspiration of the Directive to eliminate the presence of irregular migrants in the EU is evident in the obligation on Member States issue a return decision to any TCN staying without authorisation. ${ }^{88}$ Indeed the Commission has observed that the effect of the Directive is to ensure that a person is either legally present in the EU or is issued with a return decision. ${ }^{89}$

It is thus clear that though sometimes consistent with or more migrantfriendly than the ICMW, EU migration law is in some key areas less generous than ICMW standards in the rights it grants TCN s. This, however, is not in and of itself a legal obstacle to ratification by Member States as there is no legal impediment to going beyond the minimum standards required by EU legislation in this field. The claim that unilateral ratification is pre-empted by EU competence in this field is also called into question by, for example, the ratification by Italy and Germany of the ILO Convention concerning decent work for domestic workers, 2011 (No. 189). ${ }^{90}$

The claim concerning unilateral ratification does, however, serve to underline the power of the EU to influence the success or failure of the Convention. Studies have shown that the EU could play a crucial role in encouraging

87 B. Ryan (2009), 'Policy on the ICrMw in the United Kingdom', in: P. de Guchteneire, A. Pécoud and R. Cholewinski (eds), Migration and Human Rights: The United Nations Convention on Migrant Workers' Rights, Cambridge: Cambridge University Press, pp. 278294, at pp. 284-285.

88 Article 6(1), Directive 2008/115/EC of the European Parliament and of the Council of 16 December 2008 on common standards and procedures in Member States for returning illegally staying third-country nationals, oJ L 348/98, 24 December 2008.

89 Communication from the Commission to the European Parliament, the Council, the Economic and Social Committee and the Committee of the Regions: Communication on Migration сом (2011) 248 final, 4 May 2011, p. 9.

9o Subsequent to ratification by Italy and Germany, the Council issued a Decision authorising EU Member States to ratify Convention No. 189. See Council Decision of 28 January 2014 authorising Member States to ratify, in the interests of the European Union, the Convention concerning decent work for domestic workers, 2011, of the International Labour Organisation (Convention No 189), OJ L 32, 1 February 2014. Furthermore, European Commissioner for Home Affairs, Cecilia Malmström, has also urged all EU Member States to ratify Convention No. 189, as soon as possible and in any event no later than 2015. See http://europa.eu/rapid/press-release_SPEECH-14-380_en.htm. 
ratification among Member States. ${ }^{91}$ The ratification by EU Member States would of course send out a strong message of support for this core human rights instrument which may be heeded by States beyond the EU's borders. ${ }^{92}$ Asian states, for example, often wait for Western countries to take the lead when it comes to ratifying international conventions. ${ }^{93}$ It is thus encouraging that much support for ratification has been expressed at the EU level.

\subsection{EU Support for Ratification of the ICMW}

The EU has displayed a higher level of sustained institutional support for the Convention than any other polity in the region. ${ }^{94}$ The Commission in 1994 urged Member States to ratify the 'unique' Convention as a way of ensuring the full protection of the human rights of irregular migrants, such a rights-based approach being necessary to ensure the credibility of restrictive policies concerning irregular migration. ${ }^{95}$ According to the Commission ratification would also ensure that the rights accorded to migrants in the EU correspond to the highest international norms and would give eloquent testimony to the value attached by the EU to improving the situation of migrant workers and their families. ${ }^{96}$ In the intervening two decades, however, the Commission has not seen fit to repeat this recommendation, providing evidence instead that it now takes a less positive view of the Convention. ${ }^{97}$

$91 \quad$ MacDonald and Cholewinski, supra note 14, pp. 20 and 28.

$92 \quad$ Ibid., pp. 19-20.

93 N. Piper (2009), 'Obstacles to, and Opportunities for, Ratification of the ICRMw in Asia', in: P. de Guchteneire, A. Pécoud and R. Cholewinski (eds), Migration and Human Rights: The United Nations Convention on Migrant Workers'Rights, Cambridge: Cambridge University Press, pp. 171-192, at p. 177 .

94 MacDonald and Cholewinski, supra note 81, p. 387.

95 European Commission, Communication to the Council and the European Parliament on Immigration and Asylum Policies, COM(1994) 23, 23 February 1994, p. 29, paras 109-110.

$96 \quad$ Ibid., p. 35, para. 132.

97 See H. Oger (2009), 'The French Political Refusal on Europe's Behalf', in: P. de Guchteneire, A. Pécoud and R. Cholewinski (eds), Migration and Human Rights: The United Nations Convention on Migrant Workers' Rights, Cambridge: Cambridge University Press, pp. 295321, at p. 319; European Commission, Communication on Maximising the Development Impact of Migration: The EU contribution for the UN High-level Dialogue and next steps towards broadening the development-migration nexus, сом(2013) 292 final, 21 May 2013, p. 6. This Communication formed the basis of the Council Conclusions cited supra note 30 . 
The European Parliament has been more vociferous and consistent in its endorsement of the Convention. In a resolution on human rights in the $\mathrm{EU}$ in 1998 it reproached Member States for not yet having ratified the Convention and urged them to do so, repeating the call on at least eight subsequent occasions, ${ }^{98}$ most recently in 2009 in a resolution on the situation of fundamental rights in the EU. ${ }^{99}$ Support for ratification has also been expressed by two consultative bodies of the EU, namely the Committee of the Regions and the European Economic and Social Committee, with the latter going so far as to issue an own-initiative opinion in 2004 devoted specifically to the issue of ratification of the Convention. The Opinion concluded by calling on the Commission and the Council to undertake the necessary political initiatives to ensure that Member States ratify within 24 months and that the EU ratify as soon as it is in a position to sign international agreements. ${ }^{100}$ The Parliamentary Assembly of the Council of Europe has also called on the Member States of the Council of Europe to ratify the ICMW, ${ }^{101}$ a point worthy of note given that all $28 \mathrm{EU}$ Member States are also Member States of the Council of Europe.

In order to secure the additional endorsement of the Council and the Commission and ensure positive EU action, however, it would be necessary to have the support of at least a handful of influential Member States. ${ }^{102}$ This in turn, would require renewed advocacy on the part of civil society. The UN's universal periodic review may provide the spark to ignite the flames of effective civil society and Member State engagement in the issue of ratification.

98 The UN Migrant Workers Convention: Steps towards ratification in Europe, Brussels: European Platform for Migrant Workers' Rights 2007, p. 22, available online at http:// www.epim.info/wp-content/uploads/2011/o2/The-UN-Migrant-Workers-Conventionsteps-towards-ratification-in-Europe.pdf.

99 European Parliament, Texts adopted, Resolution on the situation offundamental rights in the European Union 2004-2008, P6_TA(2009)0019, 14 January 2009, para. 158, available online at http://www.europarl.europa.eu/sides/getDoc.do?type=TA\&reference=P6-TA-2oo9o019\&language $=\mathrm{EN} \&$ ring $=\mathrm{A} 6-2008-0479$.

100 EESC Opinion on the International Convention on Migrants (Own-initiative opinion), Brussels, 30 June 2004, Doc. soc/173, p. 7, para. 6.2.

101 Recommendation No. 1737 of 17 March 2006 of the Parliamentary Assembly of the Council of Europe.

102 MacDonald and Cholewinski, supra note 81, p. 387. 


\section{The UPR and Recommendations to EU Member States concerning} the ICMW

\subsection{The UPR}

The United Nations Commission on Human Rights, established in 1946 as a subsidiary body of the UN Economic and Social Council, was the UN's main political forum for the promotion and protection of human rights. By the beginning of the millennium, however, the Commission was coming under increasing criticism that politicisation of its work was compromising its effectiveness. ${ }^{103}$ The Commission thus held its final session in March 2006, with the UN General Assembly adopting resolution 6o/251 on 15 March 2006 to establish the Human Rights Council, the replacement and successor of the Commission. ${ }^{104}$

The Human Rights Council, as set out in resolution 6o/251, is a forum for discussing, reporting on and making recommendations concerning all thematic human rights issues and situations. A subsidiary organ of the General Assembly, the Council is composed of 47 UN Member States elected for threeyear terms by secret ballot and is also tasked with mainstreaming human rights within the UN system. In fulfilling its mandate the Council is to be guided by the principles of universality, impartiality, objectivity, non-selectiveness and cooperation.

In order to achieve the tasks with which it is charged, the Council has a number of mechanisms and procedures, one of which is the UPR, ${ }^{105}$ often characterised as one of the Council's flagship innovations. Resolution 6o/251 mandated the Council to conduct a universal periodic review of each State's fulfilment of its human rights obligations and commitments 'in a manner which ensures universality of coverage and equal treatment with respect to all States.' Each review should take place on the basis of objective and reliable information.

The review of each State's human rights record, conducted by the UPR Working Group, is assisted by groups of three randomly-chosen States known as the troika. The review essentially consists of an interactive dialogue where any UN Member State may direct questions, comments or recommendations to the State under review. The 'objective and reliable information' which forms

\footnotetext{
103 M. Kothari (2012), 'From Commission to the Council: Evolution of un Charter Bodies', in: D. Shelton (ed.), The Oxford Handbook of International Human Rights Law, Oxford: Oxford University Press, pp. 487-620, at p. 587 .

104 UN GA Res 6o/251 of 15 March 2006 on the Human Rights Council.

105 For more detail on the UPR, see the OHCHR website at http://www.ohchr.org/EN/ HRBodies/UPR/Pages/UPRMain.aspx.
} 
the basis of the review is drawn from three documents: the State under review submits a twenty-page National Report detailing the human rights situation in the country; the Office of the High Commissioner for Human Rights (OHCHR) prepares a ten-page compilation of $\mathrm{UN}$ information which summarises all information submitted by UN agencies and human rights mechanisms concerning the State under review; and the OHCHR also compiles a ten-page document based on the submissions of NGOs which is known as a summary of other stakeholders' information.

It is worth flagging at this juncture the many opportunities for civil society engagement which the UPR process offers. As well as the NGO submissions which inform one of the three documents upon which the review is based, civil society representatives should also be consulted by the State under review as part of the process of preparation of the National Report. Furthermore, UPR Info, a civil society initiative, organises pre-sessions in Geneva one month in advance of a State's review, bringing together civil society, National Human Rights Institutions and Permanent Missions to discuss the human rights situation in the State in question. Civil society also has a key role to play in monitoring implementation of recommendations.

Indeed the Human Rights Council has highlighted implementation of recommendations as an issue which should receive particular attention from reviewing States during the second and subsequent cycles of the UPR. ${ }^{106}$ States provide information on the measures taken to give effect to recommendations in mid-term reports and in the documents submitted as part of the State's second UPR, though the submission of mid-term reports is done on a voluntary basis and is thus not a procedure adhered to by all States.

The first cycle of the UPR, during which the human rights record of every UN Member State was examined, was conducted over the four year period between 2008 and 2011. The second and current cycle began in 2012 and has been extended to four and a half years. While the UPR process has been the subject of sharp criticism by distinguished voices from within the UN human rights milieu, ${ }^{107}$ not least because the implementation of recommendations is dependent on the good will of the State under review, the recommendations

106 Human Rights Council Resolution 16/21 of 12 April 2011 on the Review of the Work and Functioning of the Human Rights Council.

107 See, for example, O. de Frouville (2011), 'Building a Universal System for the Protection of Human Rights: The Way Forward', in: M. Bassiouni and W. Schabas (eds), New Challenges for the UN Human Rights Machinery: What Future for the UN Treaty Body System and the Human Rights Council Procedures?, Cambridge: Intersentia, Part II, Chapter 2, at pp. 250-255. 
made to the State under review provide an important indication of which human rights issues are viewed as worthy of attention by other States. At the same time, the response of the State under review to recommendations demonstrates that State's attitude to the human rights issue in question, giving it an opportunity to detail what, if anything, it plans to do to implement the recommendation.

At least one well-informed commentator is of the belief that States take the UPR more seriously than the State reporting procedure before treaty bodies. ${ }^{108}$ If this is true, it may be at least partially attributable to the accessibility and visibility of the mechanism, features which cannot go unremarked when discussing the UPR in relation to an international human rights instrument about which there has been a chronic lack of awareness. The sessions of the UPR Working Group are webcast and archived, and there is an almost immediate public availability of the documents connected with the UPR process including the three documents upon which the review is based and the resulting report of the UPR Working Group.

It is important to point out that the UN resolutions establishing and amending the UPR do not discuss State responses to recommendations in terms of acceptance and rejection, but rather provide that States may accept or note recommendations. ${ }^{109}$ Noted recommendations are those which do not enjoy the support of the State under review, but may still be implemented and monitored. The discussion which follows, for the sake of clarity and convenience, uses the terminology of acceptance and rejection adopted by States.

\subsection{UPR Recommendations to EU Member States concerning the IcMW}

An examination of the recommendations made to the $28 \mathrm{EU}$ Member States since the establishment of the UPR provides an insight into the preoccupations of both EU Member States and non-EU States in relation to migration issues, particularly the ICMW. While each EU Member State is reviewed individually, and the human rights record of the EU as an organisation is not assessed

108 M. Nowak (2011), 'It's Time for a World Court of Human Rights', in: M. Bassiouni and W. Schabas (eds), New Challenges for the un Human Rights Machinery: What Future for the un Treaty Body System and the Human Rights Council Procedures?, Cambridge: Intersentia, Part I, Chapter 1, at p. 23.

109 Human Rights Council Resolution 5/1 of 18 June 2006 on the Institution-Building of the United Nations Human Rights Council. 
during the UPR, ${ }^{110}$ a distinct $\mathrm{EU}$ approach to migration issues emerges from an investigation of the UPR process thus far.

The statistics cited in the following section have been compiled by the author on the basis of information contained in the online database of recommendations created by UPR Info. ${ }^{111}$ The figures refer to the combined total of recommendations made since the beginning of the UPR process. Some EU Member States, such as Germany, have already undergone UPR twice, while others like Belgium, have not yet been reviewed during the second cycle of UPR. This partly explains the variation in the number of recommendations to individual States concerning the ICMW.

Before turning to the issue of the Convention, however, a number of general conclusions can be tentatively drawn concerning migration-related recommendations made to EU Member States. A total of 4192 recommendations have been made to the EU 28 so far. $27 \%$ of these recommendations were made by EU Member States and $77 \%$ of the total have been accepted. The picture is somewhat different when it comes to migration-related recommendations. ${ }^{112}$ Of the 555 migration-related recommendations received by the EU 28 , only $7 \%$ were made by EU Member States and only 50\% of migration-related recommendations were accepted by the EU 28 .

It seems uncontroversial, therefore, to observe that EU Member States make remarkably few migration-related recommendations to each other, presumably viewing one another's migration laws and policies as generally sound from a human rights perspective. Further evidence of EU28 satisfaction with the treatment of migrants in the $\mathrm{EU}$ is provided by the fact that only $50 \%$ of all migration-related recommendations were accepted by EU Member States, a significantly lower proportion than the overall rate of recommendation acceptance amongst the EU28.

110 The State-centric nature of the UN is exemplified in the somewhat ironically titled UN GA Res $65 / 276$ of 3 May 2011 on the participation of the European Union in the work of the United Nations.

111 See http://www.upr-info.org/en. The statistics drawn from the database are accurate on 1 July 2014. As the UPR is an ongoing process, the database is regularly updated to take account of new recommendations. This will result in changes in the numbers of migration-related recommendations over time, though not necessarily in the trends to which they attest.

112 It is important to note here that UPR Info has 54 issue-based categorisations for recommendations. While 'migrants' constitutes one of the 54 categories, 'asylum-seekers/ refugees' and 'trafficking', both of which would come within a broad definition of migration, are separate categories in the UPR Info database. 
When it comes to rejected migration-related recommendations, most of these concern the ICMW. A total of 230 recommendations have been made to the EU 28 concerning the ICMW. These recommendations usually ask the State under review to ratify or consider ratifying the Convention. Each EU Member State has received a minimum of three recommendations to ratify or adhere to the ICMW with important destination countries such as France, Spain and the UK receiving 13 such recommendations each, and Germany the recipient of 23 recommendations concerning the Convention.

While the EU 28 generally reject recommendations to ratify the Convention, they often provide a response and explanation for the rejection. In its mid-term report in 2012 on implementation of first cycle recommendations Slovenia made the commonly-invoked argument that its national legislation already guarantees most of the rights contained in the Convention, but also noted that it cannot make a definitive statement on the issue of ratification. ${ }^{113}$

Finland's acceptance of five first cycle recommendations to consider ratification led it to explain its decision not to ratify on the basis that, inter alia, very few States have ratified the instrument. ${ }^{114}$ During the second cycle it again accepted recommendations to consider ratification, arguably displaying at the very minimum an openness to the possibility of ratification. Given the fact that a perceived prohibition on unilateral ratification is advanced by some EU States as a reason for non-engagement with the Convention, the potential impact of ratification by a single EU Member State cannot be underestimated.

Evidence that repeating recommendations in the face of initial rejections may pay dividends is provided by the behaviour of the Czech Republic. During the first cycle it rejected two requests to adhere to or consider ratifying the Convention on the grounds that national legislation offered sufficient protection of migrants' rights. ${ }^{115}$ It changed its tune during the second cycle, however, accepting two recommendations to consider ratification.

113 Republic of Slovenia, Mid-Term Report on the Implementation of UPR Recommendations, March 2012, available online at http://www.upr-info.org/sites/default/files/document/ slovenia/session_07_-_february_2010/slovenia_mid-term_report_2012.pdf.

114 Finland, National Mid-Term Report, June 2010, available online at http://www.upr-info. org/sites/default/files/document/finland/session_01_-_april_2008/finland_mid-term_ review_11junı.pdf.

115 Report of the Working Group on the Universal Periodic Review Czech Republic, Addendum: Response of the Czech Republic to the recommendations included in the Report of the Working Group on the Universal Periodic Review (A/HRC/8/33), available online at http://www.upr-info.org/sites/default/files/document/czech_republic/ session_1_-_april_2008/ahrc833addıczechrepublice.pdf. 
The States recommending ratification are, not surprisingly, already States Parties to the Convention. In the vanguard are Algeria, Egypt, Mexico, Argentina and Ecuador, with important origin countries like Philippines and Morocco also keen to see EU Member States engage with the Convention. An examination of recommendations concerning the ICMW yields a number of interesting questions and anomalies. If we take the recommendations made by, for example, Mexico, we see that it called on Poland to ratify during both the first and second cycles of the UPR, but failed to follow up its first cycle ratification recommendation to Czech Republic and Germany with a similar recommendation in the second cycle. Similarly, the question arises as to why Mexico recommended ratification to the Netherlands during the second cycle but not the first? One might also ask why Mexico has recommended ratification to 14 EU Member States, but not to the other half of Member States.

When it comes to the recommendations themselves, they are often formulated in different ways. For example during the first cycle Mexico called on Romania to ratify the Convention, urged Slovakia to 'ratify-accede-adhere' to the Convention and encouraged Austria to adhere to the principles of the Convention in view of its possible ratification. Regardless of variations in the wording of recommendations, however, the strength of the conviction of States like Mexico that EU Member States should become a party to the ICMW is abundantly clear from the regularity with which they make recommendations relating to the Convention.

\subsection{The Potential of the UPR for the ICMW}

While recommendations are not legally enforceable, as an indicator of the concerns and views of recommending States they may be viewed as carrying a moral weight. Arguably, the greater the number of recommendations which focus on the same issue, the greater the moral gravity attaching to the issue with a correspondingly greater pressure being exerted on the State under review to implement the recommendation.

Given that civil society is already thought to have played a role in increasing the rate of ratification of the ICMW ${ }^{116}$ it may not be too fanciful to suggest that the sheer volume and consistency of recommendations to the EU 28 concerning the ICMW could provide the spark needed to reignite the flames of effective civil society engagement in advocating for ratification. Indeed there

116 M. Grange and M. D’Auchamp (2009), 'Role of Civil Society in Campaigning for and Using the ICrmw', in: P. de Guchteneire, A. Pécoud and R. Cholewinski (eds), Migration and Human Rights: The United Nations Convention on Migrant Workers' Rights, Cambridge: Cambridge University Press, pp. 70-99, at p. 84. 
is some evidence to suggest that one of the effects of UPR has been to galvanise civil society. A comparison of the number of joint submissions made by civil society organisations for States which have undergone review during both the first and second cycles of the UPR reveals a marked increase in cooperation between different NGOs in most EU Member States ahead of the UPR. The number of joint submissions made by civil society in France doubled from 1 to 2 from the first cycle to the second cycle of UPR, went from 1 to 6 in Poland, from 3 to 8 in Germany and from 1 to 14 in the $\mathrm{UK}$. This is persuasive evidence of the impact that the UPR is having on civil society collaboration and coalitionbuilding in the $\mathrm{EU}$.

Furthermore, a 2012 evaluation of the UPR entitled On the Road to Implementation suggested that the mechanism offers a chance to trigger new debates ${ }^{117}$ and that it has been an effective awareness-raising and advocacy mechanism, acting above all as a catalyst for civil society to discuss human rights issues with its State. ${ }^{118}$ The report, based on a review of 66 States, noted that $15 \%$ of rejected recommendations had in fact subsequently been implemented. The engagement of civil society in a broad in-country discussion and nationwide advocacy was one of the possible explanations advanced by the report for the implementation of rejected recommendations, yielding the conclusion that without civil society action at both international and national level, rejected recommendations would not be implemented. ${ }^{119}$ Such a proposition must be viewed as particularly encouraging from the point of view of the ICMW, given the almost invariable practice of the EU 28 of rejecting recommendations to ratify.

As well as the leverage that recommendations may provide to civil society, the very fact of a recommendation forces the State under review to engage with the issue about which the recommendation is made, even when such recommendation is 'rejected'. The issue is thereby brought to the attention of the State under review and marked as something to which other members of the international community attach importance. Thus we saw Poland respond to a first cycle recommendation to ratify the ICMW by reference to analysis it had conducted in 2004 showing that Polish law guarantees migrant workers and members of their families the majority of rights accorded under the Convention. Furthermore, Poland argued, there was no need to expand migrant workers assistance services or adopt actions in cooperation with other

\footnotetext{
117 UPR Info (2012), On the Road to Implementation, Geneva: UPR Info, p. 13.

118 Ibid., p. 5 .

119 Ibid., p. 13.
} 
States, as required by ICMW, given limited scale of current emigration and immigration. ${ }^{120}$

Poland's justification of its second cycle rejection of six recommendations to ratify or consider ratifying the Convention essentially repeated the response given the first time round, but also included information to the effect that in 2013 the original analysis of the compatibility of Polish legislation with the Convention had been updated, yielding the conclusion that the amendments made to national legislation concerning migrants in the intervening nine years were not sufficient to allow ratification. ${ }^{121}$

It is clear, then, that ratification suggestions often result in State engagement with the topic of the Convention. This, coupled with the aforementioned change in attitude to such suggestions displayed by the Czech Republic, indicates that the potential importance of such recommendations should not be dismissed too lightly. Indeed, given that lack of awareness of the Convention at the domestic and international levels itself constitutes an obstacle to ratification, the very fact that the UPR has resulted in the ICMW being brought to the attention of governments and civil society in the EU 28 may in itself be considered an important achievement.

Is the ICMW still the 'best-kept secret in the UN'?122 Do recent legislative and institutional changes concerning the EU'S AFSJ make any difference to the chances of constructive EU engagement with the Convention? Can EU civil society activity around the Convention recover from the nadir represented by the dissolution in 2011 of the Brussels-based NGo December 18 which did such sterling work to promote awareness and ratification of the Convention? ${ }^{123}$ What answers, if any, does the UPR provide to these questions?

120 Republic of Poland, Universal Periodic Review, Mid-Term Progress Report by Poland, February 2010, available online at http://www.upr-info.org/sites/default/files/document/ poland/session_01_-_april_2008/poland_mid-term_report_march_2011.pdf.

121 Republic of Poland, Universal Periodic Review, Mid-Term Progress Report by Poland, January 2014, available online at http://www.upr-info.org/sites/default/files/document/ poland/session_13_-_may_2012/poland_mid-term_report_2014_.pdf.

122 De Guchteneire and Pécoud, supra note 16, p. 14.

123 Established in 1999, December 18 was a non-profit organisation which advocated for a human rights based approach to migration at the international level. Its Board of Directors announced that the organisation would be dissolved by April 2011 due to a lack of funding, though it succeeded in continuing some activities until 2013. Its website, a 
In light of the accessibility and visibility of the UPR, and given the sheer number and consistency of ICMW-related recommendations made to the EU 28 during the UPR, we might tentatively suggest that awareness of the Convention has reached a sufficiently high level to be able to cast off the epithet of bestkept secret in the UN. Similarly, the creation by the Treaty of Lisbon of an EU landscape, dominated by instruments such as the Charter and the ECHR, in which the human rights of migrants can be more easily vindicated cannot but be a positive development from the point of view of efforts to advance the issue of ratification at the EU level. Arguments around administrative and financial burdens and claims of unacceptable encroachment on States' sovereignty hold ever less water as the common EU migration space that has been evolving since 1999 accords an ever more robust catalogue of rights to all migrants, often going beyond what would be required by the ICMW. Is it overly optimistic to suggest that never before, from a legal point of view, have conditions in the $\mathrm{EU}$ been so favourable to ratification of the Convention and the legal costs of ratification to Member States so low?

Greater levels of awareness of the Convention amongst civil society and Member States and a more propitious EU legal landscape are not, however, in and of themselves sufficient to effect ratification by EU Member States. This requires further ingredients, including a convergence of political will and genuine efforts by politicians to improve the public perceptions of migrant workers and their families and tireless lobbying on the part of civil society. Along with the increased awareness of the Convention which the UPR may create, the periodic review mechanism may also contribute to galvanising civil society in the EU into action around the Convention. Apart from the many opportunities which the UPR process provides for civil society involvement more generally, the recommendations made during UPR to ratify the ICMW can be added to the advocacy armoury of civil society as an additional weapon in the fight for ratification. While the termination of the Convention-focused NGO December 18 dealt a strong blow to civil society efforts in this field, there is nothing to prevent other migrants' rights NGOs building on and continuing the work of December 18. Indeed, on this front there is renewed cause for hope. In 2013 a group of students on the human rights MA course at EIUC in Venice established the advocacy campaign Migrants Matter, ${ }^{124}$ one of the aims of which is to get the issue of ratification of the Convention back on the political agenda of the EU. Though essentially unfunded, the campaign has already

treasure trove of information concerning the ICMW and activities aimed at advancing its ratification, is unfortunately no longer available.

124 See http://migrants-matter.blogspot.it/. 
held a number of awareness-raising events and conducted lobbying at the EU level. As the campaign will pass annually from one class of human rights master's students to the next, the pool of energetic young advocates and activists engaged in the issue will grow annually, with new ideas and enthusiasm being injected into the campaign each year.

Similarly, the upcoming 25th anniversary of the adoption of the ICMW has been seized upon as opportunity to bring together civil society and other stakeholders to rally for ratification. Launched by the Migrant Forum in Asia network, Step It $\mathrm{Up}^{125}$ is a global campaign which will provide an online platform for activities relating to the promotion of the ICMW and its ratification. Such civil society activity and initiatives are essential to securing the support of a number of influential Member States, something which is a prerequisite for positive EU action vis-à-vis the Convention. Time will tell whether the UPR can contribute to re-energising civil society in the EU in relation to the ICMW and whether, despite the almost wholesale 'rejection' of ICMW-related recommendations by the EU28, the proliferation of recommendations to ratify will bring any meaningful pressure to bear on Member States and the EU. While the EU regularly expresses its commitment to the UPR, urging all countries to cooperate effectively, ${ }^{126}$ it is clear that at least for now effective cooperation with the UPR does not entail acceptance by the EU and its Member States of 200-plus recommendations to ratify one of the ten core international human rights instruments.

\section{Acknowledgements}

I am grateful to Vahan Bournazian, Mariette Grange and Tamara Lewis for very fruitful conversations on some of the topics discussed in the article. I am equally indebted to the anonymous reviewer for detailed, constructive feedback on an earlier draft. The Global Classroom, held within the framework of the Global Campus at EIUC, Venice in May 2013, first provided me with an opportunity to investigate the UPR. Websites cited were last accessed on 1 July 2014.

\footnotetext{
125 See http://cmw25.org/.

126 A recent example is to be found in para. 5, Council of the European Union, Council Conclusions on EU priorities at the UN Human Rights Fora, Foreign Affairs Council Meeting, Brussels, 10 February 2014.
} 
